In nostra nuper edita breui adnotatione ${ }^{1}$ de loco opusculi incerti auctoris, quod dicitur Didascalia apostolorum, cap. 2, 11 castigando iuxta abundans -que particulis scilicet ideo, utinam, iam... adiectum, itaque pro ita in infima latinitate aduerbialiter adhibitum sane probauimus, quod numquam ante a studiosis praeter cunctantem Szantyr ${ }^{2}$ ullo testimonio ualde conlato testatum constat. duos enim locos qui et talem dicendi usum concederent et loci nostri emendationem confirmarent, afferebamus, unum e Luciferi Calaritani Moriundum esse opusculo cap. I (p. 285 Hartel): ut enim uos negando filium dei domos esse inmundi spiritus uocibus prophetarum, apostolorum atque sacrorum euangelio rum designamini, itaque ${ }^{3}$ filium dei confitemur, templa dei esse ostendimus, alterum e Vita S. Germani Venantio Fortunato presbytero, ut uidetur ${ }^{4}$, adscripta, 44, 123 (p. 21 Krusch): eadem quoque die tacta uestis nobilis quasi impetus fluminis, itaque quartanae febris ignis omnis extinctus est. quo pro comperto Didascaliae textum sic legendum protulimus: 5 un lex est simplex, uera, sine quaestione Christianis constituta, itaque: quod tibi fieri ab alio non uis, tu alio ne feceris. et iam erat sub prelo nostrum commentariolum, cum ad nos Luciferi Calaritani noua operum editio a G. F. Diercks accuratissime parata ${ }^{6}$ per-

\footnotetext{
1 staque en lloc de ita en llati tarda in Faventia 1, 2, 1979, pp. 207-210.

2 Apud Syntax und Stilistik ( $\mathrm{Hb}$. II 2, 2, München 1972), p. 476 legitur: «itaque $=$ ita unsicher Didasc. apost. 2, 11 .

3 itaque cum mss. et Tiliana principe in nostra editione iam sub prelo, quamuis Coleti Hartel Diercks ita qui malunt.

4 uide Gregorii Turonensis Historiam Francorum 5, 8 ab Arndt editam.

5 de editoribus hunc locum uarie interpretantibus uide op. cit. in nota 1, pp. 207 208.

6 Luciferi Calaritani opera quae supersunt, CC 8, Turnholti 1978.
} 
uenit, cuius Index uerborum nobis aliud testimonium de particulae itaque pro ita usu praebuit, e libro primo De Athanasio cap. XXXIV (u. 38 Diercks) excerptum: cum haec itaque sint, temet punire conspice.

\section{LAMBERTO FERRBRES}

